\title{
Plasma digoxin levels in infants
}

\author{
K. O'MALLEY, E. N. COLEMAN, W. B. DOIG, and I. H. STEVENSON \\ From the Department of Pharmacology and Therapeutics, University of Dundee, and University Department of Child \\ Health, Royal Hospital for Sick Children, Glasgow
}

\begin{abstract}
O'Malley, K., Coleman, E. N., Doig, W. B., and Stevenson, I. H. (1973). Archives of Disease in Childhood, 48, 55. Plasma digoxin levels in infants. The average dosage rate of digoxin given in a group of infants, when related to body surface area, was twice as high (and when related to body weight, five times as high) as that employed for the maintenance therapy of adult controls. The resulting plasma digoxin level in infants older than 1 month was no higher on average than that of the adult controls $(1.4 \mathrm{ng} / \mathrm{ml})$; in those younger than 1 month it was on average 2 times higher than the adults' control value yet without toxic effect. From the preliminary findings the plasma digoxin level appears to be of limited value in regulating digoxin dosage in infancy.
\end{abstract}

Wide experience of digitalis in the treatment of congestive cardiac failure in the first year of life has not removed uncertainty as to optimal dosage, largely because a reliable measure of its pharmacological effect is lacking. It is generally held, moreover, that infants are more tolerant of cardiac glycosides than adults (Neill, 1965). In an attempt to elucidate these problems the first step undertaken was to compare plasma levels of digoxin in infants and adults, and this paper describes the findings.

\section{Patients and methods}

Patients. The infants studied were all inpatients of the Royal Hospital for Sick Children, Glasgow (Table). In all cases the indication for digoxin therapy was congestive heart failure secondary to a wide variety of congenital cardiovascular defects. The 16 adults were inpatients in general medical wards: 8 of them had ischaemic heart disease, 4 had rheumatic valvular disease, 2 had paroxysmal atrial tachycardia, the cause of which was unknown, 1 had a cardiomyopathy, and $1 \mathrm{had}$ heart failure secondary to primary polycythaemia.

Received 19 May 1972.
The indication for digoxin therapy in 5 patients was atrial arrhythmia and in the remaining 11 congestive heart failure.

Other clinical details of both groups are given in the Table. Both the adults and the infants had been on a fixed dose of digoxin for at least 5 days before blood sampling for drug assay. They were in a relatively steady clinical state and had no evidence of digoxin toxicity.

Methods. Venous samples were taken into lithium heparin for plasma digoxin assay between 6 and 7 hours after the previous dose of the drug. Plasma was stored at $-20^{\circ} \mathrm{C}$ before assay. Plasma digoxin was measured by the radioimmunoassay method (Smith, Butler, and Haber, 1969) using the commercially available Lanoxitest $\beta$ kit (modified according to Ojala, Karjalainen, and Reissell, 1972). At the same time as sampling for digoxin, plasma was taken off for urea and electrolyte estimation. A 12-lead electrocardiogram was taken about this time also in order to exclude digoxin toxicity. With all patients, height and weight were measured and surface area calculated. Statistical significance was measured using the ' $t$ ' test for unpaired observations.

TABLE

Clinical data, dose of digoxin, and plasma digoxin levels

\begin{tabular}{|c|c|c|c|c|c|c|c|}
\hline \multirow{2}{*}{ Subjects } & \multirow{2}{*}{ No. } & \multicolumn{2}{|c|}{ Age } & \multirow{2}{*}{$\begin{array}{c}\text { Blood urea } \\
(\mathrm{mg} / 100 \mathrm{ml}) \\
(\mathrm{mean} \pm \mathrm{SD})\end{array}$} & \multirow{2}{*}{$\begin{array}{c}\text { Dose } \\
(\mathbf{m g} / \mathbf{k g}) \\
(\mathrm{mean} \pm \mathrm{SD})\end{array}$} & \multirow{2}{*}{$\begin{array}{c}\text { Dose } \\
\left(\mathrm{mg} / \mathrm{m}^{2}\right) \\
(\mathrm{mean} \pm \mathrm{SD})\end{array}$} & \multirow{2}{*}{$\begin{array}{l}\text { Plasma digoxin } \\
(\mathrm{ng} / \mathrm{ml}) \\
(\mathrm{mean} \pm \mathrm{SD})\end{array}$} \\
\hline & & Mean \pm SD & Range & & & & \\
\hline $\begin{array}{l}\text { Adults } \\
\text { Infants } \\
\quad>1 \text { month } \\
<1 \text { month }\end{array}$ & $\begin{array}{r}16 \\
13 \\
5 \\
8\end{array}$ & $\begin{array}{r}66 \cdot 7 \pm 12 \cdot 0 \mathrm{yr} \\
65 \cdot 0 \pm 68 \cdot 0 \mathrm{dy} \\
135 \cdot 0 \pm 65 \cdot 4 \mathrm{dy} \\
23 \cdot 4 \pm 6 \cdot 3 \mathrm{dy}\end{array}$ & $\begin{array}{l}46-85 \mathrm{yr} \\
12-225 \mathrm{dy} \\
63-225 \mathrm{dy} \\
12-30 \mathrm{dy}\end{array}$ & $\begin{array}{l}48 \cdot 9 \pm 17 \cdot 3 \\
45 \cdot 8 \pm 14 \cdot 1 \\
44 \cdot 6 \pm 10 \cdot 4 \\
46 \cdot 5 \pm 16 \cdot 0\end{array}$ & $\begin{array}{l}0.005 \pm 0.002 \\
0.024 \pm 0.003 \\
0.024 \pm 0.005 \\
0.023 \pm 0.002\end{array}$ & $\begin{array}{l}0.18 \pm 0.09 \\
0.39 \pm 0.05 \\
0.41 \pm 0.08 \\
0.38 \pm 0.04\end{array}$ & $\begin{array}{l}1 \cdot 4 \pm 1 \cdot 1 \\
2 \cdot 8 \pm 1 \cdot 5 \\
1 \cdot 4 \pm 0 \cdot 5 \\
3 \cdot 8 \pm 1 \cdot 2\end{array}$ \\
\hline
\end{tabular}




\section{Results}

The results obtained are outlined in the Table. The mean plasma level in the adults was $1.4 \pm$ $1 \cdot 1 \mathrm{ng} / \mathrm{ml}$ and in the 13 infants $2 \cdot 8 \pm 1 \cdot 5 \mathrm{ng} / \mathrm{ml}$, the difference between these means being significant $(P<0.01)$. When those infants under 1 month were considered as a separate group there was a more obvious difference from adults. The plasma level in the children under 1 month was considerably greater than that of the adults $(P<0.001)$ or of the older infants $(P<0.01)$. There was no difference in mean plasma digoxin level between infants over 1 month and adults. Using the method of least squares, a significant negative correlation was found between age and plasma digoxin in the infants $(P<0 \cdot 05)$.

\section{Discussion}

The assumption that infants are more resistant to cardiac glycosides than adults has been made because the dose of drug tolerated in the young is larger on a weight $(\mathrm{mg} / \mathrm{kg})$ basis. Crawford, Terry, and Rourke (1950) questioned this premise on the grounds that body weight is a poor denominator. Few physiological functions can be correlated closely to weight. Much better correlations are found by using either lean body mass or surface area. In our study the difference in dose between adults and infants was of the order of fivefold when expressed on a weight $(\mathrm{mg} / \mathrm{kg}$ ) basis (Table). On a surface area basis $\left(\mathrm{mg} / \mathrm{m}^{2}\right)$ the difference was reduced to twofold. However, in the present study the overall dose used in the infants is relatively large $-0.024 \mathrm{mg} / \mathrm{kg}\left(0.39 \mathrm{mg} / \mathrm{m}^{2}\right)$. Recently Coltart, Cree, and Howard (1972) concluded that a maintenance dose of as little as $0.01 \mathrm{mg} / \mathrm{kg}$ body weight (approximately $0.18 \mathrm{mg} / \mathrm{m}^{2}$ surface area) was adequate for infants under 1 month. The absence in infancy of reliable signs to indicate an optimal myocardial concentration of digoxin makes it impossible to ascertain the ideal dose required for the treatment of heart failure. The dose given to our youngest infants was perhaps in excess of that required to gain the desired effect, but it was nevertheless well tolerated. The dosage for our 8 infants aged under 1 month was in fact only marginally lower than that for the 5 over 1 month.

Although it was in accord with the experience of Chamberlain et al. (1970), we cannot be certain that the plasma digoxin level of our adult controls was optimal, or that optimal levels for the adult and the infant are necessarily identical, or indeed that plasma level accurately reflects pharmacological effect. We consider it noteworthy, however, that the mean plasma digoxin level in the older infants $\frac{\mathrm{O}}{\mathrm{C}}$. was identical with that of the adult controls but $ᄋ$ that to achieve this equality the infant dose calculated according to body surface area was twice as: large as the adult dose. By contrast, the mean $\overrightarrow{\bar{F}}$ plasma level for infants under 1 month $(3.8 \mathrm{ng} / \mathrm{ml}) \overrightarrow{0}$ was $2 \frac{1}{2}$ times as high as that of the older infants $\frac{C}{0}$ and of the controls $(1.4 \mathrm{ng} / \mathrm{ml})$; this high level $\bar{c}$ would not be tolerated by adults (Smith et al., $\overparen{\odot}$ 1969; Chamberlain et al., 1970). It is probable that in infants older than 1 month a more rapid $\%$ elimination of the drug is the basis for the very $\overrightarrow{0}$ high dose to plasma ratio. The high plasma levels $\overrightarrow{\vec{H}}$ unaccompanied by toxic effects in the younger $\vec{\omega}$ infants may be due to slower elimination of the drug accompanied by decreased myocardial sensitivity.

In the only other study that we are aware of in which a comparison of steady state levels of digoxin in in infants and adults has been made, Coltart et al. $\mathrm{O}$ (1972) also found comparable levels in infants over 1 month and in adults. However, unlike us, they $c$ found no difference between infants over and under 1 month, a discrepancy that can be explained only partly by the higher dose used in the present study in the first month of life.

Hernandez et al. (1969) examined the pharm\& $\omega$ cokinetics of tritiated digoxin in infants and did no find a difference from adults in absorption, tissue fixation, or rate of excretion of the drug. Resulfo from animal work are somewhat conflicting (Haag and Corbell, 1940; Halloran et al., 1970; Wollenberger, Jehl, and Karsh, 1953), but it seems that, in general, as in the human situation, the newborn are more tolerant of cardiac glycosides than adults but are nevertheless less tolerant than more mature young animals (Marini, Sereni, and Bottino, 1962). Again the relative roles of myocardial sensitivity and digitalis handling are not obvious. Certainly the types of toxic arrhythmia found both in infants and in very young animals are different from that found in adults (Marini et al., 1962).

The impetus for the present study came partly from curiosity as to the basis for the use of particularly large doses of digoxin in infancy. There was also the need to determine whether the plasma digoxin level might prove to be a reliable aid to the $N$ regulation of dosage. In this age period, neither effect on heart rate nor any other physical sign can 0 indicate at what point an adequate concentration $\omega$ of the drug has been reached at its site of action in the myocardium. Clearly, plasma digoxino levels seem to be of limited value because of the $\overparen{D}$ different meaning they may convey at different $\stackrel{?}{+}$ ages in infancy, and they have been criticized 0 
elsewhere for failing to give a reliable reflection of toxicity (Fogelman et al., 1971).

We thank the Medical Research Council for financial support. The skilled technical assistance of Mr. I. Cowie is gratefully acknowledged.

\section{REFERENCES}

Chamberlain, D. A., White, R. J., Howard, M. R., and Smith, T. W. (1970). Plasma digoxin concentrations in patients with atrial fibrillation. British Medical fournal, 3, 429.

Coltart, D. J., Cree, J. E., and Howard, M. R. (1972). Plasma digoxin concentrations in children in heart failure. British fournal of Pharmacology, 44, 373P.

Crawford, J. D., Terry, M. E., and Rourke, G. M. (1950). Simplification of drug dosage calculation by application of the surface area principle. Pediatrics, 5, 783.

Fogelman, A. M., La Mont, J. T., Finkelstein, S., Rado, E., and Pearce, M. L. (1971). Fallibility of plasma-digoxin in differentiating toxic from non-toxic patients. Lancet, 2, 727.

Haag, H. B., and Corbell, R. L. (1940). The effect of age of cats on susceptibility to digitalis. Fournal of Pharmacology and Experimental Therapeutics, 68, 45.
Halloran, K. H., Schimpff, S. C., Nicolas, J. G., and Talner, N. S. (1970). Digitalis tolerance in young puppies. Pediatrics, 46, 730.

Hernandez, A., Burton, R. M., Pagtakhan, R. D., and Goldring, D. (1969). Pharmacodynamics of ${ }^{3} \mathrm{H}$-digoxin in infants. Pediatrics, 44, 418.

Marini, A., Sereni, F., and Bottino, D. (1962). Digoxin dosage in newborn animals and infants. Pediatrics, 30, 332.

Neill, C. A. (1965). The use of digitalis in infants and children. Progress in Cardiovascular Diseases, 7, 399.

Ojala, K., Karjalainen, J., and Reissell, P. (1972). Radioimmunoassay of digoxin. Lancet, 1, 150.

Smith, T. W., Butler, V. P., and Haber, E. (1969). Determination of therapeutic and toxic serum digoxin concentrations by radioimmunoassay. New England fournal of Medicine, 281, 1212.

Wollenberger, A., Jehl, J., and Karsh, M. L. (1953). Influence of age on the sensitivity of the guinea pig and its myocardium to ouabain. Fournal of Pharmacology and Experimental Therapeutics, 108, 52.

Correspondence to Dr. Kevin O'Malley, Department of Pharmacology and Therapeutics, University of Dundee, Dundee DD1 4HN. 